\title{
Correction: Non-operative management, supported by self- monitoring using web-based patient reported outcome measures (PROMs), in knee osteoarthritis
}

Webb E, Parkes RJ, Gough AT, et al. Non-operative management, supported by self-monitoring using web-based patient reported outcome measures (PROMs), in knee osteoarthritis. BMJ Case Rep 2018. doi:10.1136/bcr-2017-223560.

This article was published with an error in the funding statement. The correct funding statement should read: 'the authors have not declared a specific grant for this research from any funding agency in the public, commercial or not-for-profit sectors'.

(C) BMJ Publishing Group Limited 2018. No commercial re-use. See rights and permissions. Published by BMJ.

BMJ Case Rep 2018. doi:10.1136/bcr-2017-223560corr1

D) Check for updates

Copyright 2018 BMJ Publishing Group. All rights reserved. For permission to reuse any of this content visit http://group.bmj.com/group/rights-licensing/permissions.

BMJ Case Report Fellows may re-use this article for personal use and teaching without any further permission.

Become a Fellow of BMJ Case Reports today and you can:

- Submit as many cases as you like

- Enjoy fast sympathetic peer review and rapid publication of accepted articles

- Access all the published articles

- Re-use any of the published material for personal use and teaching without further permission

For information on Institutional Fellowships contact consortiasales@bmjgroup.com

Visit casereports.bmj.com for more articles like this and to become a Fellow 